\title{
A Review of Behavioral Tests to Evaluate Different Types of Anxiety and Anti-anxiety Effects
}

\author{
Himanshu', Dharmila ${ }^{2}$, Deepa Sarkar ${ }^{1}$, Nutan $^{1}$ \\ ${ }^{1}$ HIMT College of Pharmacy, Greater Noida, ${ }^{2}$ School of Pharmaceutical Education and Research, Jamia Hamdard, New Delhi, India
}

\begin{abstract}
Behavioral tests are very useful to understand the Neuro-psychotic disease and also helpful in finding the treatment of the particular disease. Nowadays various tests are available to evaluate the anxiolytics effect of a new entity or even for comparative studies with the standard drug. As per the ethics, a new compound or drug believes to have possible pharmacological effects should be tested on animals before tested on humans which have similar physiology than humans. First, rats were used for behavioral test for evaluation of anti-anxiety drug but later on the various strain of mice were added for evaluation of anxiolytics because of better genetic possibilities than rats. In this review article, we have discussed the most commonly used behavioral tests used to evaluate the anti-anxiety effect. Anxiolytics are the agent which are used to elevate anxiety effect produced due to any cause. The various parameter will be undertaken for the better and precise evaluation of anxiolytics.
\end{abstract}

KEY WORDS: Anxiety; Elevated plus maze; The light and dark box; Marble-burying behavior; The hole-board test; The open-field test.

\section{INTRODUCTION}

\section{Anxiety}

Anxiety is a medical state related to our psychological as well as physiological behavior having numerous characters like cognitive, emotional, behavioral and somatic. The term anxiety actually came from a Latin word "Ango" which means "to vex or torment" may be in the absence or presence of any psychological stress. It can also create a feeling of worry, feeling of fear, and feeling of uneasiness. Sometimes, it is considered a normal reaction for a stressor. Anxiety is a serious mental illness which results in various functional impairment associated with social costs [1].

GABA-A receptor system functionally associated with regulation of anxiety. Evidences which are available point out the major role of $\alpha-2$ subunit of GABA-A in modu-

Received: January 14, 2020 / Revised: March 25, 2020

Accepted: March 30, 2020

Address for correspondence: Himanshu

HIMT College of Pharmacy, Greater Noida, Uttar Pradesh 201301, India

E-mail: kapoorhimanshu12113@gmail.com

ORCID: https://orcid.org/0000-0003-3165-6857 lation of anxiety and as a result of present studies it is suggested that $\alpha-3$ subunit of GABA-A receptor could be associate with anxiety [2].

Recent data (2017) of anxiety shows that 284 Million people are affected by this disorder worldwide which includes $63 \%$ females [3].

There are 4 types of anxiety: Generalized anxiety disorder, Specific phobias, Social anxiety, and Panic disorder. There are two other conditions where anxiety disorder also present i.e., obsessive-compulsive disorder (OCD) and post-traumatic stress disorder (PTSD) as shown in Figure 1.

In case of anxiety, adrenaline is released by the nervous system when our brain sends the message in the case when we feel some danger or think that something dangerous is about to occur as a result, we feel alert and energetic and prepare us to attack or to move to safety. Mostly, the effect of anxiety is lived for the short time period when we encounter something unpleasant or outside of our comfort level but when the symptoms are severe and remains for longer duration and affects negatively on the personality, ability to work or socially which is considered as a problem [4].

(ㄷ) This is an Open-Access article distributed under the terms of the Creative Commons Attribution Non-Commercial License (http://creativecommons.org/licenses/by-nc/4.0) which permits unrestricted non-commercial use, distribution, and reproduction in any medium, provided the original work is properly cited. 


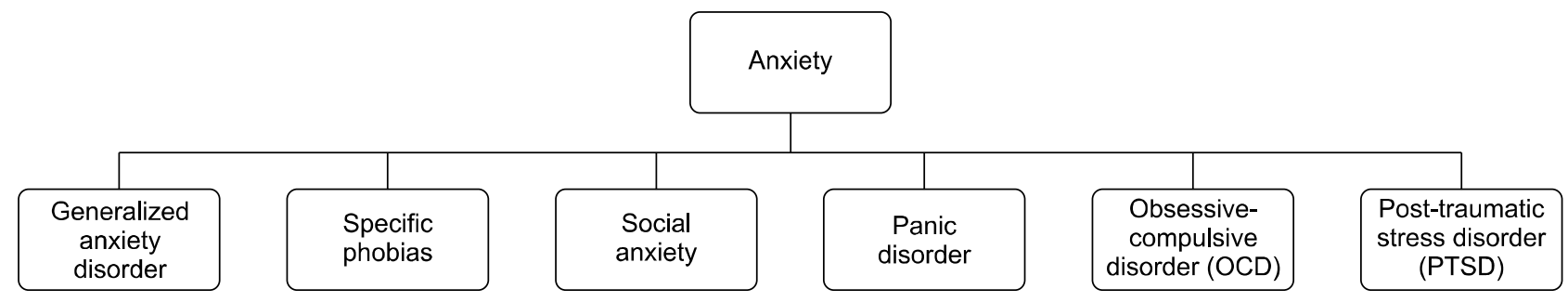

Fig. 1. Classification of anxiety disorder.

There are several factors which affect the person need to be considered are:

- The degree of distress caused due to the anxiety symptoms

- The level of effectiveness of the anxiety symptoms have on a person's ability to study or work and to socialize and manage daily task

- The context in which anxiety occurs

\section{DIFFERENT BEHAVIORAL TESTS FOR EVALUATION OF ANTI-ANXIETY DRUGS}

There are various behavioral tests which are present nowadays to evaluate any new drug moiety or in combination or to compare with the standard drug for an anxiolytic effect.

1. Elevated plus maze

2. The light and dark box

3. Marble-burying behavior

4. The hole-board test

5. Open-field test

\section{Elevated plus maze}

This is common and most simplified behavioral test which is used to evaluate behavior related to anxiety disorder in rodents. In early time, an elevated Y-shaped apparatus was offered by Montgomery in 1955 to evaluate the anxiolytic effect but later on, it was modified by Handley and Mithani in 1984 [5] and Pellow and its colleagues modified it in 1985 into an elevated plus maze with two open and two enclosed arms which were arranged to form a plus shape maze. Afterwards, the same apparatus was offered by Lister in 1987 for mice [6]. This test was investigated to evaluate fear-induces behavior i.e., anxiety. The elevated plus maze helps in rapid screening of drugs which modulate anxiety or mouse genotype such as $5-\mathrm{HT}_{1 \mathrm{~A}} \mathrm{KO}, \mathrm{CCK} 2 \mathrm{KO}$ without involvement of

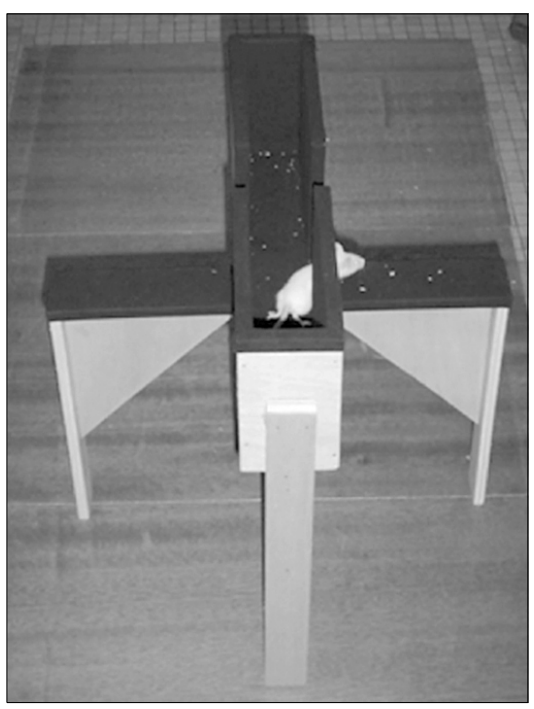

Fig. 2. A view of elevated plus maze apparatus. Adapted from the article of Bourin (Dialogues Clin Neurosci 2015;17:295-303) [7].

complex schedules or training. It has an advantage over other models or behavioral tests which uses food or water deprivation or shock administration to assess anxiety [7].

A day before experiment animals should be placed in each arm of the elevated plus maze so that animals get familiar with the apparatus and will not take time to respond while actual activity will perform.

Dimensions are specific for the elevated plus maze apparatus. It consists a plus shape maze elevated above the ground with four arms i.e., two closed arms with an open roof and two open arms positioned oppositely as shown in the Figure 2 [7]. Measurement of the apparatus can be changed according to the type of study and to get the precise result. There are different measures for different species i.e., for the rats, maze should be approximately $70 \mathrm{~cm}$ above the ground with the length and breadth of the arm is approximately $45 \mathrm{~cm}$ and $10 \mathrm{~cm}$ respectively and for the mice, maze should be approximately $30 \mathrm{~cm}$ above the ground with the length and 
breadth of the arm is approximately $30 \mathrm{~cm}$ and $5 \mathrm{~cm}$ respectively [8]. It also consists of a centre point where the animal will be placed during the experiment. A video camera also mounted above the maze for the recording of the subject's movement and analysed by a video tracking system. As rodents prefer to live in dark places and avoid light or bright places to live plus, they also have an anxiety effect with height. Therefore, time spent in the open or closed arm is calculated to measure anxiety-like behavior or the anti-anxiety effect of a drug. Ethanol of concentration $70 \%(\mathrm{v} / \mathrm{v})$ ethanol should be used to clean the maze after each and every trail and at the end of the day it should be cleaned with $10 \%$ bleach [9].

After administration of drug experiment should be started according to dose and their peak plasma level. The animal should be kept in the center with their head facing towards the open arm and the animal will start moving in different arms as per their condition. The behavior which is typically recorded is the time spent and entries made on the closed and open arms. In this task, behavior reflects a conflict between in their living preference for protected areas i.e., closed arms and their innate motivation to explore novel environments i.e., open arms.

In elevated plus maze, there is no such evidence of age-related restriction in behavioral testing. There is various data available which support that all age group rodents can be used to evaluate anti-anxiety activity of a drug [10]. But later on behavioral study was conducted which introduce that the animals having age less than 3 months experienced less anxiety on elevated plus maze and dim illuminating effect in elevated plus maze also encourage the exploration of open sides of maze [11].

Anxiolytics would be expected to increase the proportion of entries and time spent in open arms. As the number and time spent in open arm is increased it cannot be concluded that it enhancing the impulsivity as this test may not be an optimum measure of motor activity [12]. If a researcher believe that the new drug is increasing the impulsivity in animals then the impulsivity test shall be performed to correlate the result.

\section{The light and dark box}

This is another behavioral test used to evaluate the anxiolytic effect in rodents. The benzodiazepine is the only drug that shows the consistent result in this test. It has an advantage over other paradigms that it does not require prior training and easy to use and quick process [13]. The light/dark model was introduced by Grawley and was validated by Godwin in 1980 and Costal in 1989 by variation of illumination within the box and uses a different type of strain of mice [14]. In a study, an experiment was conducted on the different age group to check the whether the light and dark test reflect anxiety in each age group and it was found that adolescent rats were emerging in light more quickly than adult aged rats. It was suggested that locomotor activity is more associated with anxiety-like behavior in adolescent rats than in adult rats. In the number of light entries, no age difference was detected in between different age groups but it was found that adults made more poke in a light box that adolescents [15].

Another study was done to evaluate anxiety-like behavior in different strains of mice such as CD-1, BALB, DBA, B6 and their behavior was studied for 15 minutes for each mouse. As a result, B6 and DBA are the strains prefer light and dark box over open field test while BALB strain highly avoids the light and the dark box [16]. Later on, another study shows mice were more active in terms of undirected exploration and locomotion in their behavior and this study also indicates impairment in cognitive behavior if the study is done during the light phase as paralleled by increased avoidance behavior which is an indication of anxiety disorder [17]. Illumination also has an effect on behavior of mice which was studied and it is found a significant difference between normal and albino mice that they preferred to remain in dark box when the ambient condition in the light box was 1,000 lux while no preference was shown in any compartment when it was 0 lux [18]. Another study was done on both rats and mice and it was figured out that both rat and mice avoid the illuminating side as illumination potentiate the acoustic startle reflex which is count as a measure of anxiety [19].

Further studies show that cholinergic mechanism may be involved in restraint stress-induced neurobehavioral alteration. The time spent in the light chamber of the light and dark box was also reduced whereas pre-treatment with atropine before the restraint procedure reverse all changes induces by the restraint stress.

Its construction is very simple and is made up of wood having two chambers one bigger (Painted White) and one smaller (Painted Black) which is separated by a thin wall as shown in Figure 3 [7]. A tiny gate is also available in a 
corner of the wall to allow the animal to pass through one box to another box. A light source is also placed in the white chamber and the upper side of the apparatus is covered with a wooden plate.

Now, place the mice and allow the animal to travel from one chamber to another chamber. The total entries on each side and total time spent on each side are counted for a specific time i.e., 5-10 minutes is counted. An entry will be considered if all four paws of the animal must be placed into the opposite chamber. Now, administer the drug and again place the mice and perform the experiment as per the doses and peak plasma level. Scaling at the bottom of light and dark chamber can be used for an exact measuring of distance travelled. The movement of mice in light and dark chamber and total time spent is recorded. This light and dark box model can be used to evaluate both the anxiogenic-like and anxiolytic-like activity of drug [20].

Anxiolytics would be expected to increase the percentage of time spent in the light box.

\section{Marble-burying behavior}

This is another behavioral test to evaluate the anti-anxiety effect or obsessive-compulsive disorder behavior i.e., this test is able to detect phenotypes related to anxiety disorder and obsessive-compulsive disorders. It is also helpful in pharmacological and behavior testing. In mice, the burying of the marble is a natural defence mechanism that occurs under anxiety or condition of stress. Neophobia generally found in rodents which means fear from new or strange objects. When they meet with new or strange or

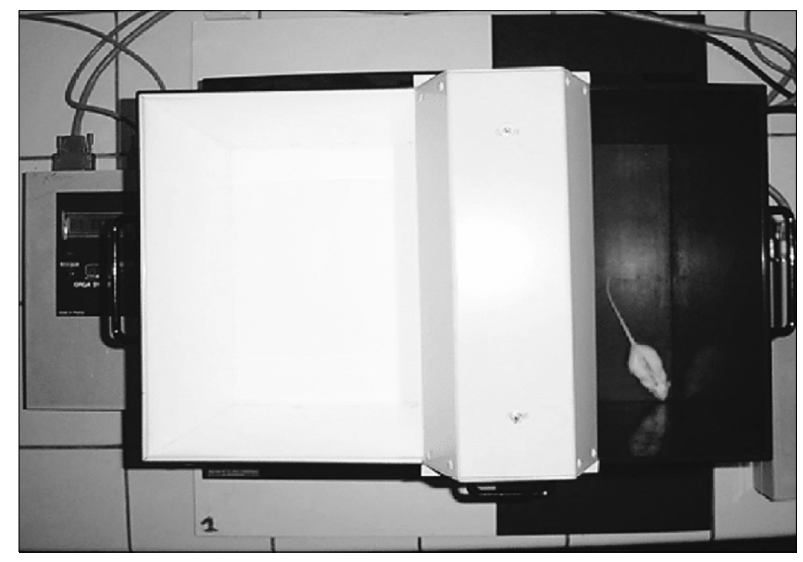

Fig. 3. The light and dark box. Adapted from the article of Bourin (Dialogues Clin Neurosci 2015;17:295-303) [7]. noxious or harmful objects, they start showing some specific type of behavior such as burrowing, digging, rearing, burying, grooming and hoarding. It means when the animal (rodents) are put in the cage with the marble they will start to bury the marble. According to studies it is seen that mice were the most preferably used in marble-burying behavior model. There is the various strain of rats such as Brattleboro, Wistar Albino, Nile Grass, Sprague Dowley, Wistar Kyoto, Lewis Rat and mice such as Swiss Albino, CD1, C57B1/6J, BALB/c, Swiss Webster Albino and NMRI mice were used and found significant variation. Lighting does have some significant effect as high-intensity light triggers off stress. So, the light and dark box must be enlightened with 60-150 lux. Handling and method of administration of the drug may vary the result. The temperature must be $23-25^{\circ} \mathrm{C}$ i.e., room temperature as variation in temperature may also vary the result. Apparatus must be cleaned with $10-70 \%$ ethanol and dried completely [21].

Standard polycarbonate cages $(26 \times 48 \times 20 \mathrm{~cm})$ are used with the fitted filter-top covers as shown in Figure 4 [22]. Unscented bedding material is added to the cage to a depth of $5 \mathrm{~cm}$ [23]. 24 Marbles are evenly distributing across the bedding and leave the animal for 30 minutes testing period. The same procedure will follow after the administration of the drug. Each animal is returned to its home cage after 30 minutes and all the marble buried $2 / 3$ rd or more will be count where less than $2 / 3$ rd buried marbles will not be count.

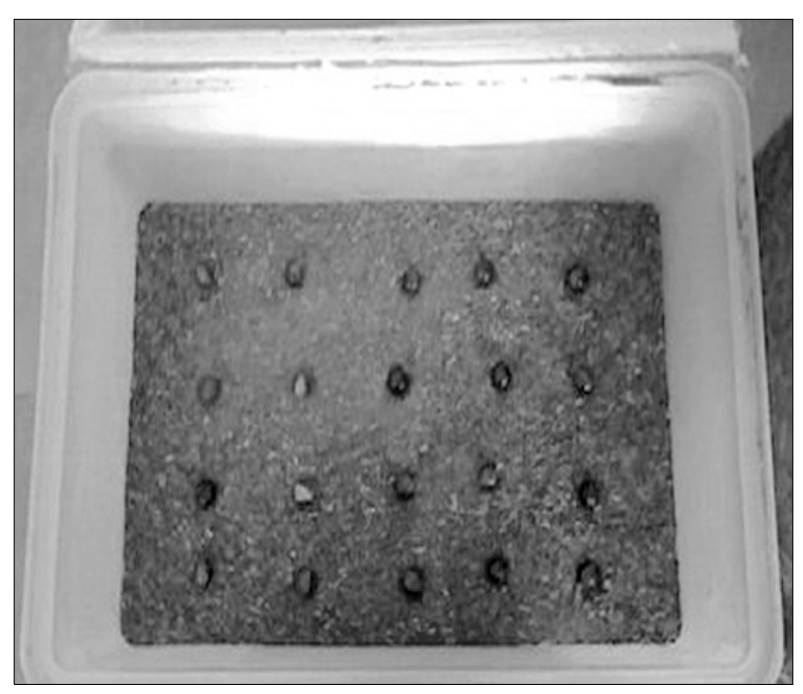

Fig. 4. Top-view of marble-burying behaviour apparatus. Adapted from the article of Prajapati et al. (Pharmacogn Res 2011;3:62) [22]. 
Recent studies show that GABA is involved in regulating compulsive behaviors along with serotonin. Thus, a marble burying behavior model may prove more useful for pharmacological drug tests of impulsivity or attention deficit because of the involvement of GABA and serotonin in both the disorders [24]. This burying behavior of rodents was first introduced by Pinel and Treit 1978. It shows that the burying of marble cannot be correlated with exploratory activity or any measure of anxiety-related response as it might be related to an animal's digging or burying activity which does not support anxiety disorder. As marble burying behavior is genetically regulated and it cannot be related to anxiety measure in other assays [25]. It also shows that the testing is independent of sex i.e., male and female both show the same type of behavior and result i.e., the number of marbles buried but most marbles were buried when they were evenly spaced. Some drugs at different doses increased and reduced the burying of marbles and also has no effect on burying on marble (e.g., diazepam at $0.1 \mathrm{mg} / \mathrm{kg}, 0.25 \mathrm{mg} / \mathrm{kg}$ and $1.0-$ $5.0 \mathrm{mg} / \mathrm{kg}$ increased, no effect and has reduced the burying of marbles respectively [26].

In a recent study, it is figured out that repeated exposure to the marbles does not cause habituation in animals suggesting that it is not related to fear because marble is non-reactive and they cannot cause harm to animals hence this 'frustrated' investigation leads to the compulsive burying. Originally, marble burying was concluded as anxiety-related behavior but later on, it was found that drug acting as serotonin reuptake inhibitors reducing the marble burying behavior which is related to obsessivecompulsive disorder. This is still a matter of debate that whether marble burying behavior measures anxiety or compulsivity [27]. Another study encourages that marble burying behavior test can also be used to evaluate drugs used in obsessive-compulsive disorder as cannabidiol reduced the repetitive behavior and containing anti-compulsive properties [28]. As per literature, anxiety is a relevant dimension of obsessive-compulsive disorder which may impact the other patient's characteristics [29]. Therefore, it is studied that marble burying may or may not reflect both neophobic/defensive (anxiety-like) behavior and inherent (compulsive-like) burying behavior [30]. In marble burying behavior, marble burying is used as an index of anxiety disorder. However, it has been argued that the marble burying behavior test is more etho- logically relevant to obsessive-compulsive disorder than any other type of anxiety disorder [31].

Another study has shown that the physical properties of bedding material and the number of marbles used in the cage significantly affect the marble burying behavior. The texture and density of bedding material are responsible for the burying of marbles. As in the observation, it was observed that more marbles were buried by mice in low density and soft bedding than high density and hard bedding. Spontaneous activity of mice was also affected by bedding material by both quantitively and qualitatively. When mice were exposed to fresh bedding then it shows high activity [32].

Anxiolytics would be expected to decrease the burying of marble.

\section{The hole-board test}

This is another behavioral test used to evaluate the anti-anxiety effect. There were various flaws in the Openfield Model so to overcome it was first introduced by Boissier and Simon in 1962 [33] and then it was developed by File and Wardill 1975 [34]. As head dipping is a point of measurement in the hole-board apparatus which was considered as a Neophiliac (Subject's attraction towards novelty) condition but the study suggested that when the animal was exposed first time to the apparatus, the animals have shown neophobic characteristic. Thus, any behavior observed in a novel environment can be influenced by both neophilia and neophobia [35]. It is also able to measure multiple behaviors that is why it is the most popular test to evaluate the anxiolytic effect. Various exploratory behavior can be evaluated in the hole board test such as head dipping and rearing. It was found that treatment with anxiogenic and anxiolytic agents affected head dipping behavior. Thus, this test can be useful in the evaluation of various changes in the emotional state of mice [36].

Traditionally, 16 holes were evenly distributed on the floor of a box $(40 \times 40 \times 25 \mathrm{~cm})$ as shown in Figure 5 . Infrared beam falling on photocells are available below the floor. The animal was placed in the box and records its locomotion (movement from one place to another place) and other behavior such as head dipping (when animal dip his head in the hole until its ears are level with the floor and break the infrared beam and rearing is when the animal stands on its hind legs. The locomotion activity is 


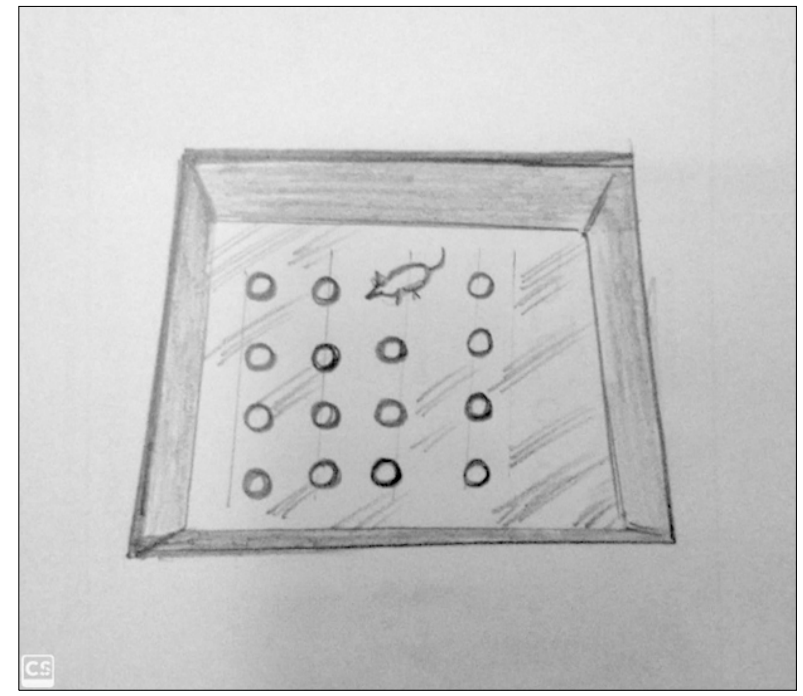

Fig. 5. A view of hole-board apparatus.

used to measure by using actophotometer as the movement of an animal interrupts a beam of infrared light falling on a photocell, at which the count is recorded and displayed digitally [37].

The modified hole board apparatus can also be used to assess multiple dimensions of various unconditioned behavior mainly in mice and rats. It includes traditional hole board apparatus and open field tests which overcomes the various disadvantages of test battery such as reducing the number of animals used, reducing time-effect and cost. The main advantage is that animals do not need to be deprived of food to increase the motivation to solve the task. This apparatus is validated for both mice and rats.

Various behavior test can be performed with the help of a modified hole board apparatus are:

a. Risk assessment

b. Avoidance behavior

c. Arousal

d. Exploration

e. Habituation

f. Cognitive

g. Social affinity

h. Locomotor activity

i. Social stress experiment

j. Novel object recognition test

It consists of an experimental box $(100 \times 50 \times 50 \mathrm{~cm})$ which was separated from an additional compartment $(50 \times$ $50 \times 50 \mathrm{~cm}$ ) by a transparent partition. In the middle of the box, a board is placed consist of some cylinders accord- ing to the test protocol. A light was also placed in the middle of the box referring to the red zone i.e., unprotected area. Two strains of mice were used in the experiment, as a result, $\mathrm{BALC} / \mathrm{C}$ J mice have shown the decreasing habituation when test under the red light condition and in normal light condition while 129P3/J has not shown any change under any condition [38]. However, testing under white light conditions may induce cognitive disruption and behavioral inhibition. In this test, it is possible to analyze the behavior of rodents and thus, it characterizes the behavioral test which mimics a psychopathological condition plus it allows to reduce the time needed and the number of animals used to perform a behavioral phenotyping [39].

Another study has shown that the hole board apparatus can be used to measure preference and avoidance response to biologically relevant odors. Various samples were placed in holes such as female urine sample, carnivore urine sample, omnivore urine sample and herbivore urine sample. As per observation, hole containing the carnivore sample was totally avoided while a hole containing female urine sample were preferred. When rats were treated with buspirone (an anxiolytic drug) avoidance of hole containing urine sample was completely abolished which indicates a specific anxiolytic action induced by the carnivore urine sample [33]. However, this test is inappropriate for the evaluation of the compound containing high sedation effects. Another study encourages the latency of head dipping when methanolic extract of Holoptelea integrifolia leaves administered orally, which indicates anxiolytic enhance the latency of head dipping of rodents when tested in hole board apparatus [40]. In the previous study, it is reported that rearing behavior is increased by dopaminergic transmission via inhibition of D3 receptors mainly found in limbic and striatum system. The exploratory activity also has been found to increase by catecholamines and serotonin by inhibition of monoamine oxidase which degrades them in the brain. Therefore, exploratory activity was enhanced by anxiolytic agents in hole board paradigm [41].

Nowadays, the use of transgenic animals has been encouraged due to specific and optimum outcomes. Hence, transgenic mice can also be used to evaluate behavioral effects of altering a specific type of neurochemical receptors i.e., $\alpha$-amino-3-hydroxy-5-methyl-4-isoxasolepropionate, $N$-methyl-D-aspartate, Dopamine, Serotonin 
and Metabotropic glutamate [42].

Anxiolytics would be expected to increase these behaviors such as locomotory, head dipping, and rearing. The animal is more anxious if the animal doesn't show these behaviors.

\section{Open-field test}

The open-field test has been first developed by Hall in 1934 which was initially used to measure emotionality behavior in rodents [43]. The open-field test provide easy and fair evaluation of behaviors which does not require pre-training [44]. This test can include other animal species such as pigs, primates, calves, honeybees, rabbits and lobsters. In 1957 and 1958 Broadhurst studied that the movement in the open-field model was mainly determined by the exploratory drive which was concluded by the detailed study of some environmental variables [45]. First it was used to measure emotionality behaviour while later on it was used to measure behavioral changes induced by psychotropic drugs and electro-convulsive shock.

Later on, Royce include monitoring of central versus oblique movement around the field in 1977. Animal which spent most of the time of experiment near central part, considered as less-fearful or less-anxious rather than those which prefer perimeter area [46]. This consideration was the informative measure of the open-field test and it was acknowledged that the other behavioral measures could be distorted by the locomotor's activity of animals.

As per the previous studies, Rodger in 1997 found that the difference in locomotor activities of individual confound the measure of emotionality which follows that the difference in emotionality of individual will confound the locomotor activity [47]. Hence, this complication seems to be largely being ignored these days.

Open-field test is widely used to assess exploratory behavior and anxiety related behavior [48]. This test is also useful particularly to assess locomotive impairment in animals having neuromuscular disease.

To perform the experiment, it would be desirable to perform the test in the night as animals are in their diurnal phase. Open-field test consists of four chambers which is used for the analysis. Measurements and lightning effects vary lab to lab. One example of measurement of openfield test is 50 (length) $\times 50$ (width) $\times 38 \mathrm{~cm}$ (height) of each chamber and it is made up of high-density and non-porous plastic. It can be of any shape and size such as rectangular, square, circular corridor and round as shown in Figure 6. Rearing, Time spent moving, Distance moved, and change in activity over time are the various measures which can be reported and tabulated. Walls has been made just to prevent the escape.

It can be visualized by installing video camera during experiment or by adding photocells-based sensors. Equal mini squares can be draw on the floor of the apparatus to count number of lines or squares crossed by animals during experiment which shows the locomotory activity precisely. Various outcomes such as center time, activity, and defecation within 5 minutes of experiment, likely gauge various aspects of emotionality including anxiety.

Each animal should be place in the center of apparatus. The person who is placing the mice should maintain no sudden motion and noise, because it can severely affect the results. Duration of test session should be 5 minutes
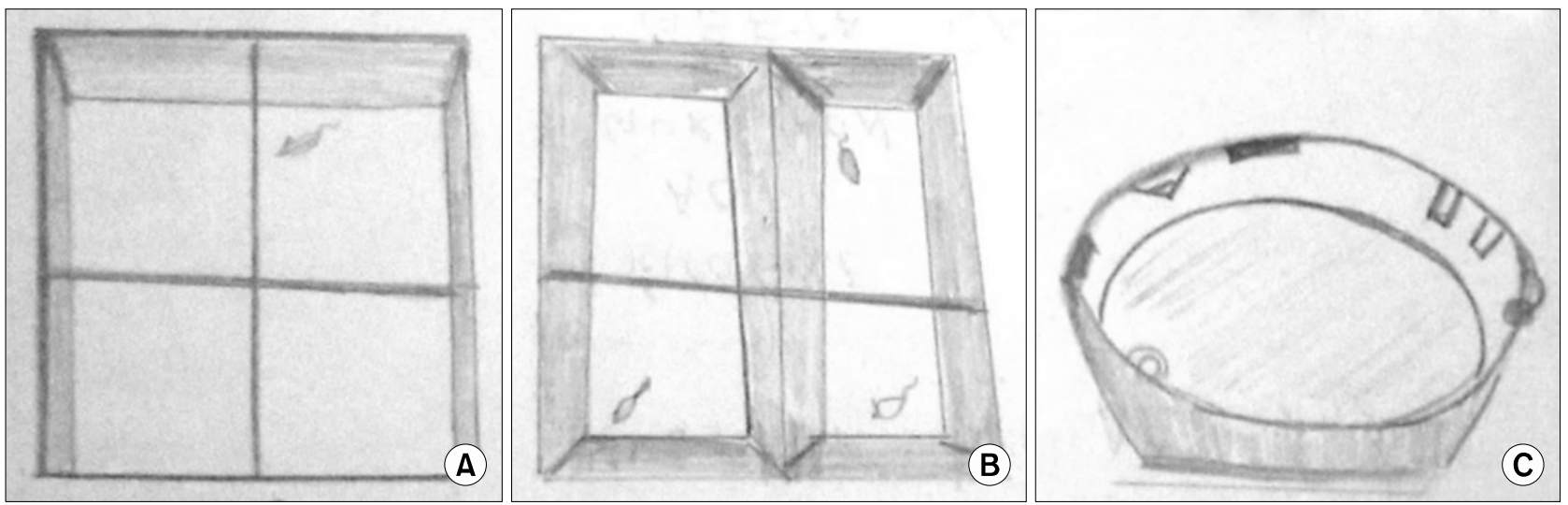

Fig. 6. Open-field apparatus of different shapes. 
Table 1. Various types of behavioral tests and their invention, animal used, and name of drugs already evaluated on them

\begin{tabular}{|c|c|c|c|c|c|c|}
\hline $\begin{array}{l}\text { Behavioral } \\
\text { tests }\end{array}$ & Invented by & $\begin{array}{l}\text { Animals } \\
\text { used }\end{array}$ & $\begin{array}{c}\text { Response to be } \\
\text { observed }\end{array}$ & $\begin{array}{c}\text { Inference of the } \\
\text { observation }\end{array}$ & $\begin{array}{l}\text { Clinically tested } \\
\text { available drugs }\end{array}$ & $\begin{array}{c}\text { Types of anxiety can } \\
\text { be evaluated }\end{array}$ \\
\hline $\begin{array}{l}\text { Elevated plus } \\
\text { maze }\end{array}$ & $\begin{array}{l}\text { Handley and } \\
\text { Mithani } \\
\text { [51] }\end{array}$ & $\begin{array}{l}\text { Mice, } \\
\text { Rats, } \\
\text { Gerbils }\end{array}$ & $\begin{array}{l}\text { Change in entries } \\
\text { and time spend in } \\
\text { open arm }\end{array}$ & $\begin{array}{l}\text { If increase: drug shows its } \\
\text { anxiolytic effect \& If } \\
\text { decrease: drug does not } \\
\text { have anxiolytic effect }\end{array}$ & $\begin{array}{l}\text { Benzodiazepines [51], } \\
\text { Barbiturates [52], Prazosin } \\
\text { [53], Clonidine [54], 5- } \mathrm{HT}_{1 \mathrm{~A}} \\
\text { receptor agonist [55], Ethanol } \\
\text { [56], Ondansetron [57] }\end{array}$ & $\begin{array}{l}\text { Generalized } \\
\text { anxiety disorder, } \\
\text { Specific phobias, } \\
\text { PTSD }\end{array}$ \\
\hline $\begin{array}{l}\text { The light and } \\
\text { dark box }\end{array}$ & $\begin{array}{l}\text { Grawley and } \\
\text { Godwin } \\
{[14]}\end{array}$ & $\begin{array}{l}\text { Mice and } \\
\text { Rats }\end{array}$ & $\begin{array}{l}\text { Change in entries } \\
\text { and time spent in } \\
\text { light box }\end{array}$ & $\begin{array}{l}\text { If increase: drug shows its } \\
\text { anxiolytic effect \& If } \\
\text { decrease: drug does not } \\
\text { have anxiolytic effect }\end{array}$ & $\begin{array}{l}\text { Paroxetine and Buspirone } \\
\text { [58], Dothiepin [59], } \\
\text { Moclobemide [60], } \\
\text { Benzodiazepines [61] }\end{array}$ & $\begin{array}{l}\text { Generalized } \\
\text { anxiety disorder, } \\
\text { Specific phobias }\end{array}$ \\
\hline $\begin{array}{l}\text { Marble } \\
\text { burying } \\
\text { behavior } \\
\text { model }\end{array}$ & $\begin{array}{l}\text { Treit and } \\
\text { Pinel [62] }\end{array}$ & $\begin{array}{l}\text { Mice and } \\
\text { Rats }\end{array}$ & $\begin{array}{l}\text { Change in the } \\
\text { number of marbles } \\
\text { buried }\end{array}$ & $\begin{array}{l}\text { If increase: drug does not } \\
\text { have anxiolytic effect \& } \\
\text { If decrease: drug shows } \\
\text { its anxiolytic effect }\end{array}$ & $\begin{array}{l}\text { Diazepam and Pentobarbital } \\
\text { [62], Nitrous Oxide [63], } \\
\text { Progesterone [64], } \\
\text { Selective Serotonin Reuptake } \\
\text { Inhibitor [65] }\end{array}$ & OCD \\
\hline $\begin{array}{l}\text { The hole } \\
\text { board } \\
\text { model }\end{array}$ & $\begin{array}{l}\text { Boissier and } \\
\text { Simon } \\
\text { [33] }\end{array}$ & $\begin{array}{l}\text { Mice and } \\
\text { Rats }\end{array}$ & $\begin{array}{l}\text { Change in } \\
\text { locomotory, head } \\
\text { dipping and head } \\
\text { rearing behavior }\end{array}$ & $\begin{array}{l}\text { If increase: drug shows its } \\
\text { anxiolytic effect \& If } \\
\text { decrease: drug does not } \\
\text { have anxiolytic effect }\end{array}$ & $\begin{array}{l}\text { Paroxetine [66], } \\
\text { Chronic Tiagabine [67], } \\
\text { Benzodiazepines [68] }\end{array}$ & $\begin{array}{l}\text { Generalized } \\
\text { anxiety, Specific } \\
\text { phobias, Social } \\
\text { anxiety disorder, } \\
\text { Panic disorder }\end{array}$ \\
\hline $\begin{array}{l}\text { The } \\
\text { open-field } \\
\text { test }\end{array}$ & Hall [43] & $\begin{array}{l}\text { Mice and } \\
\text { Rats }\end{array}$ & $\begin{array}{l}\text { Change in } \\
\text { locomotory, } \\
\text { Rearing, Time spent } \\
\text { moving, Distance } \\
\text { moved and Change } \\
\text { in activity over time }\end{array}$ & $\begin{array}{l}\text { If time spent in centre part } \\
\text { is more than time spent } \\
\text { in perimeter than drugs } \\
\text { consider as anxiolytic }\end{array}$ & $\begin{array}{l}\text { Gabapentin, } \\
\text { Carbamazepine, } \\
\text { Lamotrigine, } \\
\text { Levetiracetam, } \\
\text { Topiramate [69] }\end{array}$ & $\begin{array}{l}\text { Generalized } \\
\text { anxiety disorder, } \\
\text { Specific phobias, } \\
\text { and Panic } \\
\text { disorder }\end{array}$ \\
\hline
\end{tabular}

PTSD, post-traumatic stress disorder; OCD, obsessive-compulsive disorder.

for novel assessment but to examine the habituation to an increasingly familiar environment, a session of 30-minutes is recommended [49]. Number of lines or square crossed will be recorded automatically and at the end of the experiment result will be accessed to check exploratory behavior. It was originally introduced for the rats but eventually it was found equally successful for the mice. In scientific research, this test is used to evaluate anxiety and locomotor activity levels in rodents. Many compound like triazolobenzodiapenes (such as alprazolam, SSRI and adinazolam) which has various spectrum of its pharmacological effect as an anxiolytic in various anxiety (like Panic disorder, Generalized anxiety disorder and OCD) have shown very less potency as an anxiolytic when tested in open-field test [50]. However, this study suggests that this paradigm optimum for exploratory behavior and locomotory measurement rather than anxiety-like behavior. The open-field test is qualitatively and quantitatively used to measure willingness to explore and general locomotor activity in rodents. However, the extent to which rodent's behavior in the test correlates with the general locomotor activity in various other situations such as in a home-cage or an activity on a wheel, is still controversial.

\section{COMPARATIVE STUDY OF ANTI-ANXIETY BEHAVIORAL TESTS}

Comparison of these various behavioral tests which are used to study or evaluate anti-anxiety effect of various drugs, along with their invention (when and by who) and animals used on these tests has been mentioned below in the Table 1 [14,33,43,51-69].

\section{CONCLUSION}

In current living system everyone has a topic of becoming anxious. Every person from student age to older age everyone is affected by tension, fear and other unpleasant factors. Anxiety is common nowadays, but it is counted as a disorder when its symptoms remain last long. Generally, symptoms of anxiety are short-lived but when it starts affecting the functioning systems mainly cognitive, physical 
and behavioral. Sometimes, it is good to have anxiety because it encourages us for survival, it leads us to concentrate on our concern to protect our self from danger or harmful situations.

Various behavioral tests have been developed to evaluate different types of anxiety such as Social phobias, Specific phobias, Panic disorder and Generalized anxiety disorder. There are two other conditions where anxiety disorder also present i.e., OCD and PTSD. Every behavioral test has some advantages and disadvantages over other paradigms. Various parameters are involved which are used to evaluate if a drug or compound carrying an anxiolytic effect or not. Some paradigms such as the modified hole board test can be used to evaluate more than one type of anxiety disorder. Whereas, some paradigms such as marble burying behavior test is a point of argument that only the burying of marble cannot be calculated as a parameter of anxiety because it can be possible that in search of food, mice dig the bedding and as a result, marble buried due to digging.

\section{Acknowledgments}

I am grateful to the faculties of HIMT College of Pharmacy, Greater Noida and all my friends (Mamta Naagar, Ruchi Sangwan, Pankaj Yadav, Nihar Sharma, Jatin Kapoor and Dhavisha Rani) for their valuable time and support.

\section{Conflicts of Interest}

No potential conflict of interest relevant to this article was reported.

\section{Author Contributions}

Conceptualization: Himanshu, Dharmila, and Nutan. Data acquisition: Deepa Sarkar and Himanshu. Formal analysis: Dharmila. Supervision: Nutan. Writing-original draft: Himanshu. Writing - review \& editing: Nutan and Dharmila.

\section{ORCID}

Himanshu

Dharmila

Deepa Sarkar

Nutan https://orcid.org/0000-0003-3165-6857 https://orcid.org/0000-0001-8804-5075 https://orcid.org/0000-0001-5369-2926 https://orcid.org/0000-0002-2961-0975

\section{REFERENCES}

1. Wang SM, Kim JB, Sakong JK, Suh HS, Oh KS, Woo JM, et al. The efficacy and safety of clonazepam in patients with anxiety disorder taking newer antidepressants: a multicenter naturalistic study. Clin Psychopharmacol Neurosci 2016;14:177183.

2. Navarro JF, Burón E, Martín-López M. Anxiolytic-like activity of SB-205384 in the elevated plus-maze test in mice. Psicothema 2006;18:100-104.

3. Ritchie H, Roser M. Mental health [Internet]. Our World in Data; 2018 Apr [cited at 2019 Sep 22]. Available from: https://ourworldindata.org/mental-health.

4. Rector NA, Bourdeau D, Kitchen K, Joseph-Massiah L. Anxiety disorders: an information guide. Canada:Centre for Addiction and Mental Health;2008. p.5-6.

5. Komada M, Takao K, Miyakawa T. Elevated plus maze for mice. J Vis Exp 2008;(22):e1088.

6. Pawlak CR, Karrenbauer BD, Schneider P, Ho YJ. The elevated plus-maze test: differential psychopharmacology of anxiety-related behavior. Emot Rev 2012;4:98-115.

7. Bourin M. Animal models for screening anxiolytic-like drugs: a perspective. Dialogues Clin Neurosci 2015;17:295-303.

8. Mulder GB, Pritchett K. The elevated plus-maze. Contemp Top Lab Anim Sci 2004;43:39-40.

9. Gulinello M. Elevated plus maze [Internet]. Pelham: Behavioral Core Facility, Albert Einstein College of Medicine [cited at 2019 Sep 29]. Available from: http://www.biobserve.com/behavioralresearch/wp-content/uploads/sites/2/2016/05/ Elevated-Plus-Maze.pdf.

10. Leo LM, Pamplona FA. Elevated plus maze test to assess anxiety-like behavior in the mouse. Bio-Protoc 2014;4:e1211.

11. Albani SH, Andrawis MM, Abella RJ, Fulghum JT, Vafamand $\mathrm{N}$, Dumas TC. Behavior in the elevated plus maze is differentially affected by testing conditions in rats under and over three weeks of age. Front Behav Neurosci 2015;9:31.

12. Walf AA, Frye CA. The use of the elevated plus maze as an assay of anxiety-related behavior in rodents. Nat Protoc 2007;2: 322-328.

13. Bourin M, Hascoët M. The mouse light/dark box test. Eur J Pharmacol 2003;463:55-65.

14. Patel PK, Chandel SS, Venkatachalam T, Sahu J, Janghel V. Pharmacological models to appraisement of antianxiety activity in experimental animals. Int J Green Pharm 2018;12(3 Suppl):S449-S457.

15. Arrant AE, Schramm-Sapyta NL, Kuhn CM. Use of the light/ dark test for anxiety in adult and adolescent male rats. Behav Brain Res 2013;256:119-127.

16. Fraser LM, Brown RE, Hussin A, Fontana M, Whittaker A, O'Leary TP, et al. Measuring anxiety- and locomotion-related behaviours in mice: a new way of using old tests. Psychopharmacology (Berl) 2010;211:99-112.

17. Roedel A, Storch C, Holsboer F, Ohl F. Effects of light or dark phase testing on behavioural and cognitive performance in 
DBA mice. Lab Anim 2006;40:371-381.

18. Thiels E, Hoffman EK, Gorin MB. A reliable behavioral assay for the assessment of sustained photophobia in mice. Curr Eye Res 2008;33:483-491.

19. Ibironke GF, Olley SM. Cholinergic modulation of restraint stress induced neurobehavioral alterations in mice. Afr J Biomed Res 2014;17:181-185.

20. Hascoët M, Bourin M, Nic Dhonnchadha BA. The mouse light-dark paradigm: a review. Prog Neuropsychopharmacol Biol Psychiatry 2001;25:141-166.

21. Çalışkan H, Şentunali B, Özden FM, Cihan KH, Uzunkulaoğlu $\mathrm{M}$, Çakan $\mathrm{O}$, et al. Marble burying test analysis in terms of biological and non-biological factors. J Appl Biol Sci 2017;11: 54-57.

22. Prajapati RP, Kalaria MV, Karkare VP, Parmar SK, Sheth NR. Effect of methanolic extract of Lagenaria siceraria (Molina) Standley fruits on marble-burying behavior in mice: Implications for obsessive-compulsive disorder. Pharmacogn Res 2011;3:62.

23. Angoa-Pérez M, Kane MJ, Briggs DI, Francescutti DM, Kuhn DM. Marble burying and nestlet shredding as tests of repetitive, compulsive-like behaviors in mice. J Vis Exp 2013; (82):50978.

24. Taylor GT, Lerch S, Chourbaji S. Marble burying as compulsive behaviors in male and female mice. Acta Neurobiol Exp (Wars) 2017;77:254-260.

25. Thomas A, Burant A, Bui N, Graham D, Yuva-Paylor LA, Paylor R. Marble burying reflects a repetitive and perseverative behavior more than novelty-induced anxiety. Psychopharmacology (Berl) 2009;204:361-373.

26. Njung'e K, Handley SL. Evaluation of marble-burying behavior as a model of anxiety. Pharmacol Biochem Behav 1991;38:63-67.

27. Chaudhary S, Yadav A, Patel N, Singhvi I. Study of agomelatine for the reduction of marble buying behavior in brain disorder. J Adv Pharm Edu Res 2016;6:1-5.

28. Nardo $M$, Casarotto PC, Gomes FV, Guimarães FS. Cannabidiol reverses the $M C P P$-induced increase in marble-burying behavior. Fundam Clin Pharmacol 2014;28:544550.

29. Wolmarans de W, Stein DJ, Harvey BH. Of mice and marbles: novel perspectives on burying behavior as a screening test for psychiatric illness. Cogn Affect Behav Neurosci 2016;16: 551-560.

30. Diniz JB, Miguel EC, de Oliveira AR, Reimer AE, Brandão ML, de Mathis MA, et al. Outlining new frontiers for the comprehension of obsessive-compulsive disorder: a review of its relationship with fear and anxiety. Braz J Psychiatry 2012;34 Suppl 1:S81-S91.

31. Homma C, Yamada K. Physical properties of bedding materials determine the marble burying behavior of mice (C57BL/6J). Open Behav Sci J 2009;3:34-39.

32. Cryan JF, Sweeney FF. The age of anxiety: role of animal mod- els of anxiolytic action in drug discovery. Br J Pharmacol 2011;164:1129-1161.

33. Wernecke KE, Fendt M. The olfactory hole-board test in rats: a new paradigm to study aversion and preferences to odors. Front Behav Neurosci 2015;9:223.

34. File SE, Wardill AG. The reliability of the hole-board apparatus. Psychopharmacologia 1975;44:47-51.

35. Brown GR, Nemes C. The exploratory behaviour of rats in the hole-board apparatus: is head-dipping a valid measure of neophilia? Behav Processes 2008;78:442-448.

36. Takeda H, Tsuji M, Matsumiya T. Changes in head-dipping behavior in the hole-board test reflect the anxiogenic and/or anxiolytic state in mice. Eur J Pharmacol 1998;350:21-29.

37. Dutt Garg V, Dhar VJ, Sharma A, Dutt R. Experimetal model for antiaxiety acyivity: a review. Pharmacologyonline 2011; 1:394-404.

38. Labots M, Van Lith HA, Ohl F, Arndt SS. The modified hole board--measuring behavior, cognition and social interaction in mice and rats. J Vis Exp 2015;(92):e52529.

39. Ohl F, Holsboer F, Landgraf R. The modified hole board as a differential screen for behavior in rodents. Behav Res Methods Instrum Comput 2001;33:392-397.

40. Kavaya Sree K, Vijusha M, Rajani A, Hemamalini K. Screening of behavioural, muscle co ordination and anxiolytic activities of methanolic extract of holoptelea integrifolia (ROXB). Int Res J Pharm 2013;4:90-94.

41. Takem LP, Eshiet GA, Ogom OG, Mbang UU. Exploratory and anxiety potentials of aqueous extract of Phragmanthera capitata. J Phytopharmacol 2014;3:400-404.

42. Brown RE, Stanford L, Schellinck HM. Developing standardized behavioral tests for knockout and mutant mice. ILAR J 2000;41:163-174.

43. Hall CS. Emotional behavior in the rat. I. Defecation and urination as measures of individual differences in emotionality. J Comp Psychol 1934;18:385-403.

44. Seibenhener ML, Wooten MC. Use of the Open Field Maze to measure locomotor and anxiety-like behavior in mice. I Vis Exp 2015;(96):e52434.

45. Stanford SC. The Open Field Test: reinventing the wheel. J Psychopharmacol 2007;21:134-135.

46. Royce JR. On the construct validity of open-field measures. Psychol Bull 1977;84:1098-1106.

47. Rodgers RJ. Animal models of 'anxiety': where next? Behav Pharmacol 1997;8:477-496; discussion 497-504.

48. Tatem KS, Quinn JL, Phadke A, Yu Q, Gordish-Dressman H, Nagaraju K. Behavioral and locomotor measurements using an open field activity monitoring system for skeletal muscle diseases. J Vis Exp 2014;(91):51785.

49. The open field and animal behavior [Internet]. ResearchGate; 2015 [cited at 2020 Mar 14]. Available from: https://www. researchgate.net/publication/272575845_The_Open_field_ and_Animal_behaviour.

50. Prut $\mathrm{L}$, Belzung C. The open field as a paradigm to measure the 
effects of drugs on anxiety-like behaviors: a review. Eur J Pharmacol 2003;463:3-33.

51. Handley SL, Mithani S. Effects of alpha-adrenoceptor agonists and antagonists in a maze-exploration model of 'fear'-motivated behaviour. Naunyn Schmiedebergs Arch Pharmacol 1984;327:1-5.

52. Wilks LJ, File SE. Evidence for simultaneous anxiolytic and aversive effects several hours after administration of sodium phenobarbitone to the rat. Neuropsychobiology 1988;19: 86-89.

53. Filip M, Baran L, Siwanowicz J, Chojnacka-Wójcik E, Przegaliński E. The anxiolytic-like effects of 5-hydroxytryptamine3 (5-HT3) receptor antagonists. Pol J Pharmacol Pharm 1992;44:261-269.

54. Hogg S. A review of the validity and variability of the elevated plus-maze as an animal model of anxiety. Pharmacol Biochem Behav 1996;54:21-30.

55. Braun AA, Skelton MR, Vorhees CV, Williams MT. Comparison of the elevated plus and elevated zero mazes in treated and untreated male Sprague-Dawley rats: effects of anxiolytic and anxiogenic agents. Pharmacol Biochem Behav 2011;97: 406-415.

56. Moser PC, Tricklebank MD, Middlemiss DN, Mir AK, Hibert MF, Fozard JR. Characterization of MDL 73005EF as a 5-HT1A selective ligand and its effects in animal models of anxiety: comparison with buspirone, 8-OH-DPAT and diazepam. Br J Pharmacol 1990;99:343-349.

57. Lister RG. The use of a plus-maze to measure anxiety in the mouse. Psychopharmacology (Berl) 1987;92:180-185.

58. Hascoët M, Bourin M, Nic Dhonnchadha BA. The influence of buspirone, and its metabolite 1-PP, on the activity of paroxetine in the mouse light/dark paradigm and four plates test. Pharmacol Biochem Behav 2000;67:45-53.

59. Bourin M, Redrobe JP, Hascoet M, Baker GB, Colombel MC. A schematic representation of the psychopharmacological profile of antidepressants. Prog Neuropsychopharmacol Biol Psychiatry 1996;20:1389-1402.

60. De Angelis L, Furlan C. The anxiolytic-like properties of two selective MAOIs, moclobemide and selegiline, in a standard and an enhanced light/dark aversion test. Pharmacol Biochem Behav 2000;65:649-653.

61. Crawley J, Goodwin FK. Preliminary report of a simple animal behavior model for the anxiolytic effects of benzodiazepines. Pharmacol Biochem Behav 1980;13:167-170.

62. Treit D, Pinel JP, Fibiger HC. Conditioned defensive burying: a new paradigm for the study of anxiolytic agents. Pharmacol Biochem Behav 1981;15:619-626.

63. Czech DA, Quock RM. Nitrous oxide induces an anxiolytic-like effect in the conditioned defensive burying paradigm, which can be reversed with a benzodiazepine receptor blocker. Psychopharmacology (Berl) 1993;113:211-216.

64. Picazo O, Fernández-Guasti A. Anti-anxiety effects of progesterone and some of its reduced metabolites: an evaluation using the burying behavior test. Brain Res 1995;680:135-141.

65. Joel D. Current animal models of obsessive compulsive disorder: a critical review. Prog Neuropsychopharmacol Biol Psychiatry 2006;30:374-388.

66. Sillaber I, Panhuysen M, Henniger MS, Ohl F, Kühne C, Pütz $\mathrm{B}$, et al. Profiling of behavioral changes and hippocampal gene expression in mice chronically treated with the SSRI paroxetine. Psychopharmacology (Berl) 2008;200:557-572.

67. Thoeringer CK, Erhardt A, Sillaber I, Mueller MB, Ohl F, Holsboer $\mathrm{F}$, et al. Long-term anxiolytic and antidepressant-like behavioural effects of tiagabine, a selective GABA transporter-1 (GAT-1) inhibitor, coincide with a decrease in HPA system activity in C57BL/6 mice. J Psychopharmacol 2010;24:733-743.

68. Ohl F, Sillaber I, Binder E, Keck ME, Holsboer F. Differential analysis of behavior and diazepam-induced alterations in C57BL/6N and BALB/C mice using the modified hole board test. J Psychiatr Res 2001;35:147-154.

69. Zimcikova E, Simko J, Karesova I, Kremlacek J, Malakova J. Behavioral effects of antiepileptic drugs in rats: are the effects on mood and behavior detectable in open-field test? Seizure 2017:52:35-40. 